\title{
Indirect effect of puromycin on memory
}

\author{
STANISLAV REINIS, Department of Physiology, Ghana \\ Medical School, Accra, Ghana
}

Swiss albino mice were trained to take the food from the food magazine in a conditioning chamber. Light for $10 \mathrm{sec}$ acted as a conditioning stimulus. When the mice were fully trained, they were injected intraperitoneally by a brain extract from untrained mice which Puromycin was administered intracranially. After the injection of the extract of Puromycin affected brains, the performance of the trained mice in the experimental space decreased almost to the performance of untrained animals.

Flexner et al (1963) reported that Puromycin, a drug blocking transfer of peptides from polypeptidyl-t-RNA to aminoacyl-t-RNA, can block the expression of memory. This effect was explained by the interruption of protein synthesis in the affected brain. Lately, Cohen \& Barondes (1967) criticized this opinion and showed that Puromycin evoked convulsive electrical activity in the hippocampus. Recently Flexner (1967) reported that the performance of Puromycinaffected animals was blocked for several months, but intracerebral injection of saline removed the blockage. Mentioned findings, therefore, show that the effect of Puromycin is probably more complex. We tried to analyze the effect of Puromycin on memory by a method similar to "memory transfer" (Reinis 1968).

\section{METHOD}

Swiss albino mice (20-25 g) males were trained in a conditioning chamber $29 \times 18 \times 12 \mathrm{~cm}$. In the shorter wall of the chamber a swinging door $3 \times 5 \mathrm{~cm}$ was placed which covered the food magazine. A light above the transparent swinging door acted as a conditioning stimulus. The conditioning stimulus lasted for $10 \mathrm{sec}$ during which a food pellet was dropped into the food magazine. If the animal collected the food during the conditioning stimulus, the conditioned reaction was considered positive. The period between conditioning stimuli lasted $80 \mathrm{sec} ; 10$ trials were applied in one session. Mice were considered to be trained when they gave 10 positive responses in a session. Twenty sessions (200 conditioning stimuli) applied to each animal were usually sufficient. Animals which were not able to be trained during 20 sessions were not used for this experiment.

The second group of mice was not trained at all. They were slightly narcotized by ether and the skin of their heads cut in the middle line. A thin intradermal needle was inserted into the skull through the temporal muscle. $20 \mu \mathrm{g}$ of Puromycin dissolved in $.03 \mathrm{ml}$ of distilled water were injected to each hemisphere. This dose is sufficient for the blockage of the performance of trained animals. It was found in control experiments, when the trained animals got $20 \mu \mathrm{g}$ of Puromycin to each hemisphere. Their performance decreased from 10 conditioned reactions in one session to 0.78 . Intraperitoneal injection of the same dose was ineffective.

The drug was administered into the subdural space in the temporal region. We tried to avoid damage to the brain tissue. The spreading of the solution on the surface of each hemisphere was easily observed through the transparent skull. Twenty-four hours after injection, the mice were sacrificed by decapitation. The brains were quickly removed and homogenized in a glass homogenizer for 2 min with $2 \mathrm{ml}$ of distilled water. The homogenate was shaken for $4 \mathrm{~h}$, left in the refrigerator at 1-3 deg C overnight and centrifuged at 4000 $\mathrm{rpm}$ for $2 \mathrm{~h}$. All procedures with the exception of the extraction in the refrigerator were performed in a room temperature 22-24 deg C.

Clear supernatant of the centrifuged homogenate of the brain of Puromycin-affected animals was injected intraperitoneally into the trained mice. The extract from one brain was always injected to one animal-acceptor. After the injection, the mice were deprived of food for $24 \mathrm{~h}$ and then were tested for the performance in the experimental chamber.

The following control groups were tested and compared with the main studied group:

(1) Trained mice injected by the extracts of salineaffected brains. Instead of Puromycin, $.03 \mathrm{ml}$ of physiological saline were injected to each hemisphere of the untrained animal, otherwise, the procedure was identical with that described above.

(2) Untrained mice injected by the extracts of saline-affected brains.

(3) Untrained mice injected by the extract of Puromycin-affected brains.

(4) Untrained mice without any injected placed for the first time into the experimental chamber.

All the results were statistically evaluated by rank correlation analysis for dichotomic ranks (Wilcoxon's test).

\section{RESULTS}

The results are summarized in Table 1. Intraperitoneal injection of the brain extracts from saline-treated brains does not affect performance of the trained animals at all. On the contrary, an extract from Puromycin-treated brains reduces the performance of trained animals almost to the level of untrained ones. There is a significant difference between trained animals injected by saline-treated brain extracts and Puromycin-treated brain extracts $(S=120, p<.0001)$. There are no significant differences between untrained animals without any injection, with the injection of extracts from Puromycin-treated and saline-treated brain.

\section{DISCUSSION}

This experiment shows probable mechanism of memory blockage by Puromycin. Puromycin blocks protein synthesis, but also induces the production of defective polypeptides. In our experiment, we were able to extract them and induce analogical changes of performance in another animal by the extract. Therefore, we suppose that blockage of the expression of memory after Puromycin is not caused only by the block of protein synthesis, but also by the formation of pathological products which are able to change the activity of nerve cells. It is then expressed in electrophysiological changes as well as in memory expression. The question, how they affect the nervous activity, is still open.

There is another possible explanation of our experiments. Puromycin injected intracranially to donor animals may be extracted back from the brain, with the brain extract

Table 1

Number of Conditioned Responses after the Application of Brain Extracts

\begin{tabular}{lcccc}
\hline $\begin{array}{c}\text { Intracerebral } \\
\text { injection to the } \\
\text { donor }\end{array}$ & $\begin{array}{c}\text { Acceptor } \\
\text { animals }\end{array}$ & $\begin{array}{l}\text { Av value of CR } \\
\text { before injection } \\
\text { of brain extract }\end{array}$ & $\begin{array}{l}\text { Av value of CR } \\
\text { after injection } \\
\text { of brain extract }\end{array}$ \\
\hline Puromycin & Trained & 12 & 10.00 & 1.83 \\
Saline & Trained & 10 & 10.00 & 10.00 \\
Puromycin & Untrained & 16 & - & 1.19 \\
Saline & Untrained & 12 & - & 1.58 \\
No donor & Untrained & 22 & - & 1.27 \\
\hline
\end{tabular}


administered intraperitoneally to the recipient animal and finally absorbed by the brain of the recipient. But this mechanism is highly improbable. Moreover, intraperitoneal injection of $40 \mu \mathrm{g}$ of Puromycin does not affect the performance of animals in our experimental situation. It was found in our control experiments when we tested the correct doses of Puromycin.

\section{REFERENCES}

COHEN, H. D., \& BARONDES, S. H. Puromycin effect on memory may be due to occult seizures. Science, 1967, 157, 333-334.

FLEXNER, L. B., FLEXNER, J. B., \& ROBERTS, R. B. Memory in mice analyzed with antibiotics. Science, $1967,155,1377-1383$.
FLEXNER, J. B., FLEXNER, L. B., \& STELlAR, E. Memory in mice as affected by intracerebral puromycin. Science, 1963, 141, 57-59.

REINIS, S. Block of "memory transfer" by Actinomycin D. Nature, $1968,220,1$.

\section{NOTES}

1. We are indebted to Professor J. V. McConnell from the Mental Health Research Institute in Ann Arbor, Michigan and to Sigma Chemical Company, St. Louis, Mo., for Puromy cin samples.

2. Further, we are grateful for technical assistance to Mr. D. E. Laryea and Mr. S. D. Foli as well as to Mr. G. K. Agbenu for the construction of the necessary equipment.

\section{(Continued from page 43)}

Table 1

Mean Relative Frequency of Responses in C-2N, Range of Relative Frequencies, and Number of Sessions

\begin{tabular}{|c|c|c|c|c|c|}
\hline \multirow[b]{2}{*}{ Condition } & \multirow{2}{*}{$\begin{array}{l}\text { No. of } \\
\text { sessions }\end{array}$} & \multicolumn{2}{|c|}{ B-3 } & \multicolumn{2}{|c|}{ B-4 } \\
\hline & & Mean & Range & Mean & Range \\
\hline Scopolamine & 8 & .54 & $.51-.57$ & $.50^{*}$ & $.45-.53$ \\
\hline Methyl scopolamine & 2 & .66 & .64 .67 & $.61^{*}$ & \\
\hline Saline & 6 & $.60^{*}$ & $.54-.66$ & $.59 *$ & $.53-.68$ \\
\hline No injection & 5 & $.63^{*}$ & $.58-.67$ & .68 & $.63-.72$ \\
\hline
\end{tabular}

* Data from one session of these conditions were not included due to equipment failure or failure of the $S$ to respond during the session.

\section{RESULTS}

Figure 1 compares cumulative records from each of the four experimental conditions for both rats. The records from the no-injection control sessions show the pattern of responding typical of this reinforcement schedule: a pause after reinforcement followed by responding until reinforcement occurs again. Following TO (i.e., nonreinforcement) the pause was generally shorter, yielding a higher overall response rate during intervals following reinforcement omission. In contrast, the records for the scopolamine condition reveal no temporal discrimination during the fixed intervals; both rats began responding as soon as reinforcement or TO was over and continued to respond at a fairly steady, low rate. The actual "running" rate on scopolamine days was lower as the records show. The data from the saline and methyl scopolamine conditions resembled the no-injection sessions showing the fixed-interval scallop indicative of temporal control. There was no systematic effect of time-out duration across the four experimental conditions.

If we consider the ratio of responses in C-2 following reinforcement omission to the total number of responses during $\mathrm{C}-2 \quad(\mathrm{C}-2 \mathrm{~N} / \mathrm{C}-2)$ we have an index of the effect of reinforcement omission. If there is no effect, responding should be equal across all $\mathrm{C}-2$ intervals and the ratio should be .5 ; the greater the omission effect, the larger the ratio. Table 1 records the average relative frequency of $\mathrm{C}-2 \mathrm{~N}$ responses for each of the four experimental conditions. Rat B-4 showed no omission effect under the scopolamine condition, while B-3 showed a slight effect (.54). Much larger omission effects were obtained in the other three conditions for both animals.

\section{DISCUSSION}

The results of this study are in agreement with the findings of Herrnstein (1959) and Boren \& Navarro (1959); administration of scopolamine eliminates the typical fixedinterval scallop. The rats responded throughout the entire fixed interval rather than pausing for a period of time after reinforcement before beginning to respond. The fact that the pattern of responding during the methyl scopolamine condition did not differ from the pattern during the other control conditions (see Fig. 1) is evidence that the fixed-interval scallop is controlled by a central rather than a peripheral mechanism. Thus, bar-pressing following reinforcement on FI schedules can be described as centrally inhibited; as this inhibition slowly decays over time bar-pressing begins again.

The omission effect was eliminated $(B-4)$ or substantially reduced (B-3) by the administration of scopolamine (cf. Table 1). If the omission of reinforcement results in a motivational reaction (an increase in drive in Hullian terms) then it might be expected that the resulting increase in response rate would be observed even when the rats were under the influence of scopolamine. On the other hand, if the elevation in response rate following reinforcement omission on fixed-interval schedules is due to absence of the usual inhibitory effect of reinforcement, as has been previously suggested elsewhere (Staddon, 1967), then the simultaneous elimination both of the FI scallop and the omission effect seen here is quite predictable, since both involve the same inhibitory mechanism. The present results, therefore, give some support to a nonmotivational analysis of interval schedule "frustration" effects.

\section{REFERENCES}

AMSEL, A. The role of frustrative nonreward in noncontinuous reward situations. Psychological Bulletin, 1958, 55, 102-119.

AMSEL, A., \& ROUSSEL, J. Motivational properties of frustration: I. Effect on a running response of the addition of frustration to the motivational complex. Joumal of Experimental Psychology, 1952, 43, 363-368.

BOREN, J. J., \& NAVARRO, A. P. The action of atropine, benactyzine, and scopolamine upon fixed-interval and fixed-ratio behavior. Journal of the Experimental Analysis of Behavior, 1959, 2, 107-115.

CARLTON, P. L. Cholinergic mechanisms in the control of behavior by the brain. Psychological Review, 1963, 70, 19-39.

CARLTON, P. L. Brain acetylcholine and habituation. In P. B. Bradley and M. Fink (Eds.), Progress in Brain Research. Vol. 28. New York: Elsevier, 1968. Pp. 48-60.

DAVENPORT, J. W., FLAHERTY, C. F., \& DYRUD, J. P. Temporal persistence of frustration effects in monkeys and rats. Psychonomic Science, 1966, 6, 411-412.

DAVENPORT, J. W., \& THOMPSON, C. I. The Amsel frustration effect in monkeys. Psychonomic Science, 1965, 3, 481-482.

HERRNSTEIN, R. J. Effects of scopolamine on a multiple schedule. Joumal of the Experimental Analysis of Behavior, 1959, 4, 351-358.

STADDON, J. E. R. Attention and temporal discrimination: Factors controlling responding under a cyclic-interval schedule. Journal of the Experimental Analysis of Behavior, 1967, 10, 349-359.

STADDON, J. E. R., \& INNIS, N. K. An effect analogous to "frustration" on interval reinforcement schedules. Psychonomic Science, $1966,4,287-288$.

WAGNER, A. R. The role of reinforcement and nonreinforcement in an "apparent frustration effect." Journal of Experimental Psychology, $1959,57,130-136$.

\section{NOTE}

1. Research supported by Grant MH11525 from the National Institute of Mental Health and grants from the National Research Council of Canada. Thanks are due to Dr. Gary C. Walters, University of Toronto, for supplying drugs and technical assistance. Reprints may be obtained from the authors, Department of Psychology, Duke University, Durham, North Carolina 27706. 